\title{
Transgenic Virus-Resistant Papaya: The Hawaiian 'Rainbow' was Rapidly Adopted by Farmers and is of Major I mportance in Hawaii Today
}

\author{
Carol Gonsalves \\ 789 Hoolaulea Street \\ Hilo, Hawaii 96720 \\ David R. Lee \\ Department of Applied Economics and Management \\ 248 Warren Hall \\ Cornell University \\ Ithaca, NY 14853

\section{Dennis Gonsalves} \\ U.S. Pacific Basin Agricultural Research Center \\ 99 Aupuni Street, Suite 204 \\ Hilo, HI 96720
}

Corresponding author: Carol Gonsalves. carol.gonsalves@verizon.net

\section{I ntroduction \\ Rainbow is the premier example of a genetically engineered horticultural crop that made it to market. It is a dream come true for scientists who wished to provide a virus-resistant papaya cultivar for the people of Hawaii. But it is also a dream come true for farmers who had lost so much papaya production to Papaya ringspot virus (PRSV) that they were "almost broke already!" Farmers had waited patiently, kept abreast of the latest news from the scientists, and went to

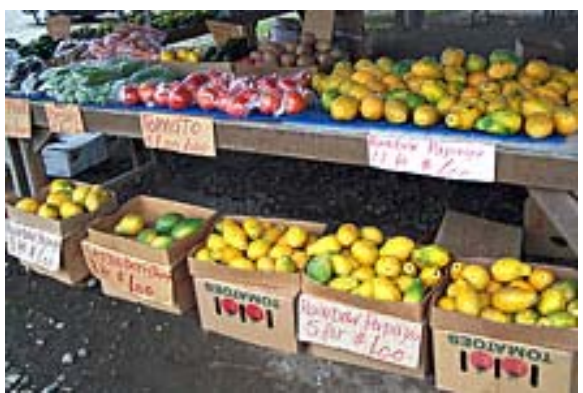 \\ Fig. 1. July 2004: Papaya vendors routinely sell Rainbow and other papaya varieties at farmers markets, small grocery stores and supermarkets in Hawaii. Seen here, a showcase at the popular Hilo bay farmers market on the island of Hawaii. \\ observe the ongoing field tests. One of the farmers mused, "Rainbow, the only hope." Gonsalves et al. wrote about that hope in 1998, "Transgenic Virus-Resistant Papaya: New Hope for Controlling Papaya ringspot virus in Hawaii, then again in 2004, "Transgenic Virus- Resistant Papaya: From Hope to Reality for Controlling of Papaya ringspot virus in Hawaii" $(4,5)$. Gonsalves, a professor in the Department of Plant Pathology at Cornell University at the time he helped develop, test, and commercialize the genetically engineered Rainbow and SunUp PRSV-resistant papaya varieties, and his wife Carol Gonsalves, who worked in his laboratory as a volunteer, decided it was imperative to go beyond the scope of plant pathology in order to measure whether farmers in their home state of Hawaii would adopt the transgenic varieties. In this article, we report on the extremely high initial rate of farmer adoption of Rainbow papaya, based on our survey of essentially all of the registered commercial papaya farmers in the Puna area of Hawaii, the Big Island, where up to $96 \%$ of the state's crop (fresh and processed) was grown.}




\section{Events Prior to the Survey}

Papaya ringspot virus raised havoc on papaya farms from the time it first appeared in 1992 in Puna, Hawaii's major papaya-growing region, until 1998 when seed of Rainbow, a transgenic virus-resistant variety, were released to farmers. During this six-year period, Puna's share of statewide production of the more lucrative fresh fruit market fell from $95 \%$ to below $78 \%$. Puna's problems were reflected in the drop of statewide fresh papaya production from 55.8 million pounds in 1992 to 35.7 million pounds in 1997, just four months prior to the commercial release of Rainbow. This data was reported in the USDA report on Hawaii Papayas, as cited by Gonsalves et al. (5).

Papaya ringspot virus is a killer. Once a plant is infected, it can never recover. Aphids feeding on the leaves of infected papaya trees effectively transmit the virus within seconds of probing on healthy trees. Symptoms begin to appear in about three weeks after infection. Young seedlings die quickly and never grow to produce fruit. Older trees develop yellowed leaves. They produce smaller and smaller fruit and are doomed to a slow death. The viral epidemic that occurred in Puna could not be stemmed by a statewide effort to remove all the infected trees in the area.

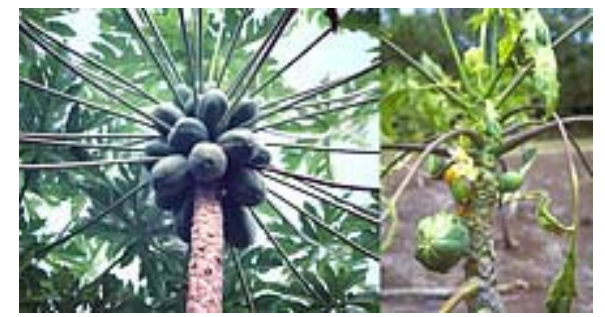

Fig. 2. Looking up into the canopy of a healthy, productive papaya tree (left) versus one that is infected with Papaya ringspot virus (right).

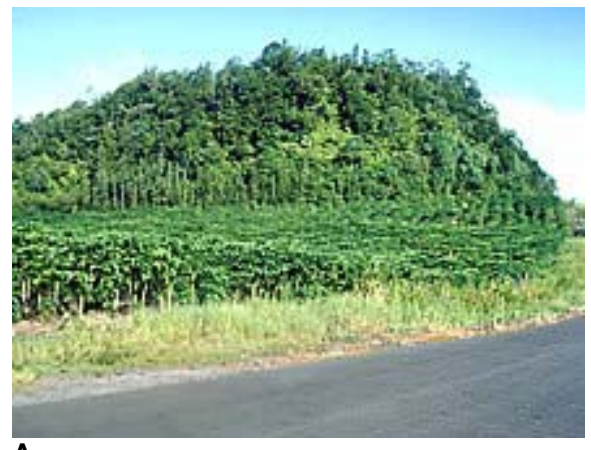

A

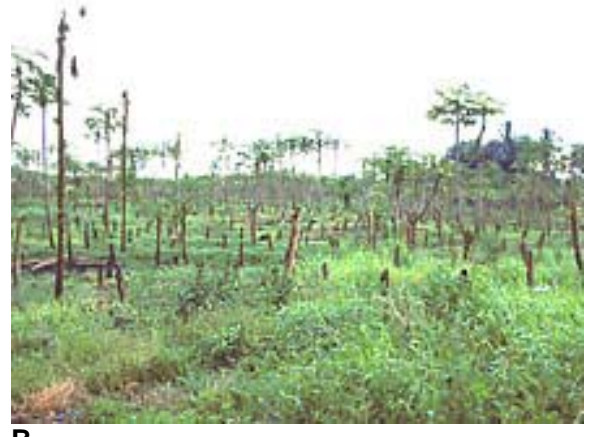

B

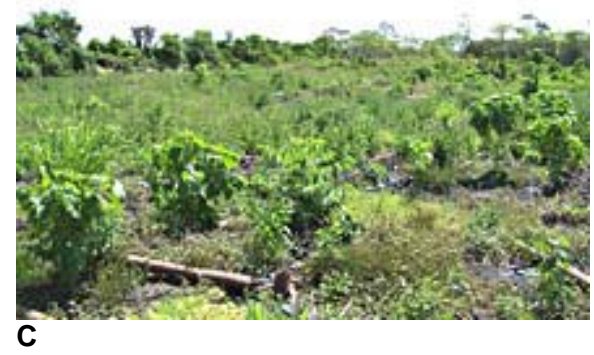

Fig. 3. Effect of rapid virus spread through commercial fields. A healthy commercial papaya field in Puna, on the verge of the viral epidemic in 1992 (A). Many papaya fields were abandoned by papaya farmers ( $\mathrm{B}$ and $\mathrm{C}$ ). 


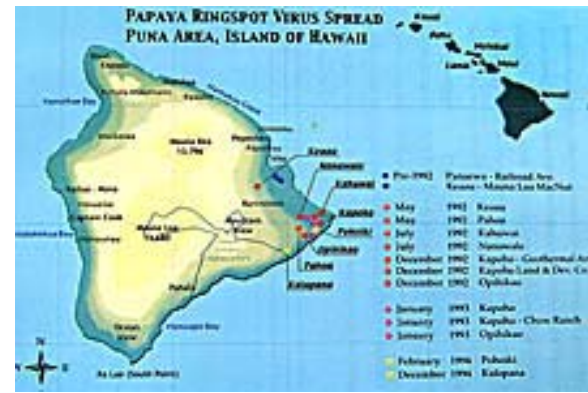

Fig. 4. Rapid transmission of Papaya ringspot virus to all of the Puna papaya farm areas occurred within two years of the discovery of the virus in a Puna field. Source: Gonsalves, C. 2001.

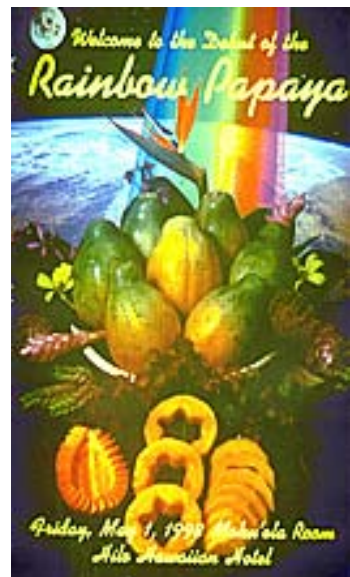

Fig. 5. Debut of Rainbow in 1998. On May 1, 1998 a celebratory Hawaiian feast attended by hundreds, including farmers, papaya industry personnel, researchers, politicians, the USDA's Assistant Secretary, Michael Dunn, and others marked the commercial release of transgenic seeds of virus-resistant Rainbow and SunUp papaya.

\section{The Survey}

Planning. The objective of the research project was to capture adoption data at the earliest timeframe possible in the Puna area on the island of Hawaii since most of the state's production was located there. This project was self-funded and the work was a thesis project couched within a Master of Arts degree in Liberal Studies from Empire State College (State University of New York), with the assistance of thesis advisor David Lee of Cornell University (2). During the planning stage, C. Gonsalves made several trips to the Puna area and Hilo to learn more about papaya farmers and to gather information from persons who were involved with the papaya industry, including personnel at papaya packing houses, the University of Hawaii, the Papaya Administrative Committee (PAC), Hawaii Agricultural Research Center (who had been contracted by the Papaya Administrative Committee to produce transgenic papaya seeds for the farmers), Hawaii Department of Agriculture, Hawaii Agricultural Statistics Service (HASS), and USDA personnel. The latter, who were working with the PAC, were helpful in advising us on how to obtain the list of commercial papaya farmers through the process provided by the Freedom of Information Act (FOIA) (7). The abovementioned core group provided essential information and help concerning the farmers, farming practices, and cultural considerations, for a broader understanding of the Hawaii papaya industry. Visits were made to all of the farming locations in Puna so that a survey questionnaire could be written, decisions on sampling methods could be made, and a pretest of the survey could be done.

Methodology. Many of the farms had been abandoned after they were overcome by the virus, and the farmers (most of whom lease rather than own farmlands) were no longer actively farming. Other farms were in isolated or difficult-to-reach areas. Thus, a decision was made to obtain names of Puna farmers through FOIA from the PAC's list of all papaya farmers in the state of Hawaii and to pick a sample to interview from that list. Since the PAC was under the oversight of 
the USDA, and all farmers who sold papayas were required to register with the PAC, this seemed to be the best practice to follow. Unfortunately, since the papaya industry was in disarray due to the effects of farm closings, the list of 524 farmers and some papaya industry businesses was greatly overstated and not even close to the current number of papaya farms reported by HASS (as determined by the number of farms selling at least $\$ 1000$ worth of papayas per year). HASS and other industry personnel estimated that there were only about 300 active farmers in the state of Hawaii. After discussing this problem with the manager of the PAC, he suggested that a reapplication be made through FOIA for the list of farmers who had registered to use transgenic seeds when they became available. In his estimation, this list would include all currently active papaya farmers. Thus, the names and addresses of 256 farmers, 202 of whom resided on the island of Hawaii with 171 of these farming in Puna, was subsequently received. (Note: At the time of the interview, one of the Puna-based farmers had re-located his papaya farm to the Hamakua Coast in an effort to escape the virus).

Diligent efforts were made to contact all of the 171 farmers in Puna, first by telephone and if there was no response or if no telephone number was available, by letter. Many of the farmers could not be located either by telephone or by letter, and it was not known whether or not they still lived in the area. Of the farmers who were contacted, only a few turned down the opportunity to be interviewed. In all, 93 of the 171 farmers (54\%) were interviewed.

All of the interviews were done by $\mathrm{C}$. Gonsalves with questions asked in a consistent manner. Generally, a day of telephone calling, setting up interviews and obtaining directions to homes or other locations alternated with a full day of interviews. Sometimes the first interview started at 7:30 a.m. and the last one at 7:30 p.m. Times and locations of interviews were at the discretion of the farmer. While most farmers wanted to be interviewed at home others requested to be interviewed at their farm, at the PAC office, on a bench outside a doctor's office, at a table outside of a supermarket, in a fast food restaurant, at a papaya packer's meeting room, or in their truck in a shopping center parking lot -- while the interviewer stood next to the truck the whole time -- quite a feat, since most interviews took about an hour to complete.

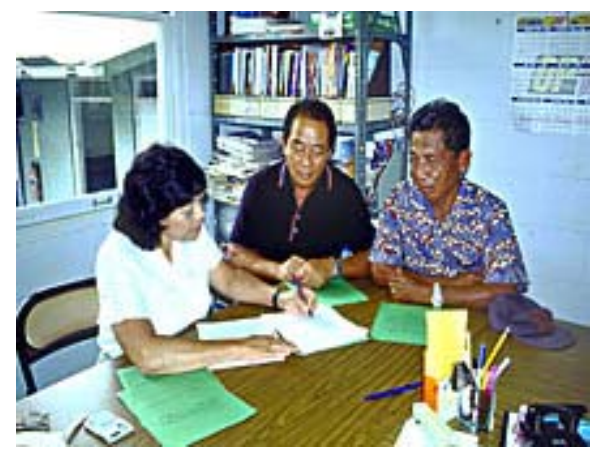

Fig. 6. Carol Gonsalves interviewing companion farmers at the Papaya Administrative Committee's conference room.

When evening interviews were scheduled along isolated, unlit roads, a reconnaissance trip was taken during the day, to assure success in locating the house at night. Some of the attempts at 
finding a home were challenging and amusing. One farmer couldn't remember any street names where he lived, but assured the interviewer that his house was easy to find because he had five pine trees in the yard. The interviewer drove in the general vicinity for some time, scanning the landscape for a house with five tall pine trees, and was chagrined to find that the homeowner had five small evergreen plants in the yard. Another farmer insisted he could be found sitting under a mango tree in the middle of a "camp" of houses, but on the day of the interview it was raining and not a soul was sitting under the tree. All data were collected during three extended visits to Hawaii from June to September, 1999.

\section{Survey Results}

Farmers were characterized as having adopted the use of the transgenic variety if they had planted seeds of the variety Rainbow between May 1, 1998 (when they became available) and the end of the survey period. Based on this definition, the adoption rate of this new cultivar was astounding, at $76 \%$. Of the 93 respondents, 92 had prepared to receive the free seeds by attending a mandatory education session or watching a video about transgenic papayas and by signing a sublicensing form. A large number of farmers (90\%) had already obtained seed.

Results that may be of interest to this readership appear below. These results are drawn from Gonsalves (2) and Gonsalves, Lee, and Gonsalves (3), which report further details.

\section{Description of farmer sample}

o 93 respondents: 84 men and 9 women

o Ages ranged from 22 to 73 years (average age 47)

- Education completed (in U.S. or Philippines)

- $29 \%$ elementary or high school

- $43 \%$ high school

- $28 \%$ college or other postgraduate school

o Ethnic heritage: Filipino 91\%, Japanese 4\%, Caucasian/other $4 \%$

o Residence location in relation to farm in Puna

- $90 \%$ resided in Keaau or Pahoa

- $10 \%$ resided in Hilo, Honokaa, Pahala, and Pepeekeo

- Family income from papaya farm(s)

Percent of family income supplied from the papaya farm in previous year

- $12 \%$ of families earned $76-100 \%$ of income from farm

- $26 \%$ of families earned $50-75 \%$ of income from farm

- $74 \%$ of families earned $<50 \%$ of income from papayas

- $32 \%$ of families earned $0 \%$ of income from papayas

o Hours spent weekly working on the farm (not all farmers reporting)

- 40 hours per week $=29$ farmers

- 60+ hours per week $=14$ farmers

- 91 hours per week = 1 farmer

- Many farmers (46\%) also held off-farm jobs, working 15 to 70 hours per week

o Many farmer spouses (47\%) also worked on the farm 2.5 to 70 hours weekly and many worked at off-farm jobs 


\section{Farmer adoption of Rainbow papaya}

o 92 farmers were "qualified" to receive seeds by completing three obligatory steps: (i) sign up, (ii) attend an education session or watch a video explaining transgenic papayas and how to grow them, and (iii) sign a sublicensing form. It's important to note that due to an equitable distribution plan, all of the farmers did not receive seeds at the same time, but over a number of months, based on three levels of priority favoring those who were "currently and historically most affected" by Papaya ringspot virus, and on four prescribed distributions. For example, in the first distribution, top priority farmers received two allotments of two ounces of seeds, for a total of four ounces (6). Each two-ounce packet contained about 4,000 seeds, or enough to plant a half acre parcel.

- $90 \%$ obtained seed

o 76\% planted seed ("adopters")

-19\% were harvesting Rainbow fruit

A subset (34 of the 93 farmers interviewed) of adopting farmers were located in the Kapoho area, the first and most severely PRSV-damaged area in Puna. Of these: - 94\% obtained seed - 88\% planted seed ("adopters")

- 29\% harvesting first Rainbow fruit

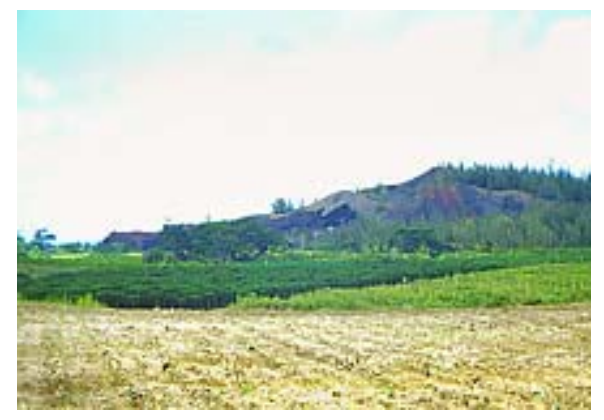

Fig. 7. Farms in the Kapoho area of Puna were most severely damaged by Papaya ringspot virus. Thus, it is not surprising that $94 \%$ of the Kapoho farmers interviewed had obtained seed, and $29 \%$ were already harvesting fruit. At the time of the interviews farmers were actively transforming the landscape from one with fields of infected trees (background, yellow trees), to one where the virus-susceptible Kapoho solo were being cut down and replaced by the virus-resistant Rainbow (foreground), and finally to lush fields of Rainbow that were bearing fruit (background, green trees). 91 farmers expressed their foremost reasons for planting or
wanting to plant Rainbow (multiple responses allowed):

o 87 (96\%) Resistance to PRSV

- $17(19 \%)$ Decrease production risk

- $15(16 \%)$ Experiment with transgenic papaya

o $12(13 \%)$ Higher profit 
Rapid adoption once farmers obtained their seeds

Of the 71 farmers who adopted (planted their seed):

- 38\% planted less than a month after receiving seeds

$042 \%$ planted after the first, but before the third month

- $20 \%$ planted between the fourth and ninth month

\section{3 farmers expressed their foremost reasons for delaying or not planting their seeds. The most frequent responses centered on the lack of farmer preparation (multiple responses allowed):}

o $21(33 \%)$ didn't have land

o $13(21 \%)$ weren't ready (needed to prepare land, etc.)

$013(21 \%)$ didn't have enough seeds

o $11(17 \%)$ didn't have enough money

Some of the farmers were concerned over market approval of transgenic papaya by Japan and Canada, whether local packing houses would buy their papaya, and whether the transgenic papaya would perform well for other farmers. However, none of the farmers were personally against the use of genetically-modified plants.

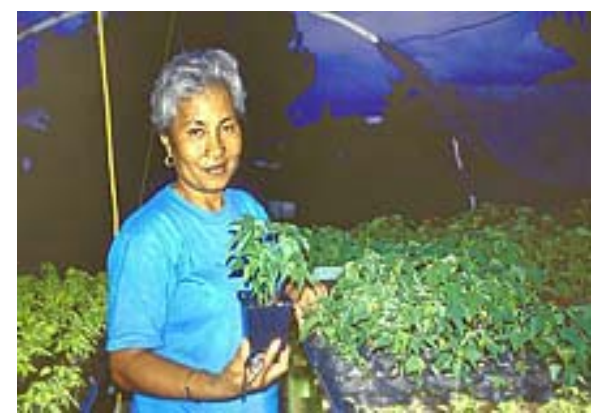

Fig. 8. Due perhaps to the special value of the Rainbow seeds, farmers experimented in establishing Rainbow seedlings in pots or trays prior to transplanting them out to the field; this was in contrast to the traditional practice of sowing about 15 seeds directly into the planting hole to ensure survival of direct seeded plants from destruction by mice, birds, slugs, pathogens, water damage, and other pests.

\section{* Production information}

- First-year cost of producing one acre of nontransgenic papaya. A preliminary study and discussions with industryrelated personnel and some of the farmers suggested that for many farmers there would be a sensitivity to answering questions on farming costs and production, and that many of them would not be able to provide specific cost and production data. Thus, although specific questions were asked in the survey, we followed the suggestion of one of the farmers who said that while many farmers probably could not answer all the specific questions about production costs, they would be able to provide their total cost of production "from the time they clear the land, until the time they begin to harvest." The farmer assured us that this question would account for costs during the first year (12 months) of the nontransgenic papaya growing cycle. All (100\%) of the farmers responded to this question, but their responses varied widely, depending on their farm needs: 
- First-year production cost: ranged from $\$ 800$ to $\$ 7,500$ per acre

- Average first-year production cost: $\$ 2,515$ per acre

- Farmers knew some costs and information precisely, such as the specific acreage of land they were leasing, and the cost per acre of leased land, as well as land clearing, seed, and topsoil that had to be hauled in to fill the rocky lava planting holes. A number of items were considered to be "free" by many farmers. These included the cost of nontransgenic Kapoho solo seeds produced on-farm, labor contributed by family or friends, and operating a tractor or truck that they owned. Further specific information follows:

- Land cost. Eighty-five of the growers farmed on leased land. The remaining eight growers farmed on their own land. Eighty-two of the 85 farmers who leased land spent an average of $\$ 132$ per acre, although the range of lease costs went from a high of $\$ 650$ to a low of $\$ 70$ per acre per year. Only one farmer (one who owned land) placed a value on the per acre use cost (at $\$ 100$ per year).

- Land clearing. The average cost of land clearing was $\$ 422$ per acre based on responses from eighty-four of the 85 farmers who leased land. Seven of the eight farmers who owned their land and responded to this question had an average per acre cost of $\$ 1,721$ (with the lowest cost at $\$ 500$ and the highest at $\$ 3,000$ ).

- Nontransgenic seed cost. Twenty-two farmers placed a value on the cost of nontransgenic seed planted per acre, from a high of $\$ 300$ per acre, to a low of $\$ 3$ per acre, with an average cost of $\$ 27$ per acre. Seven farmers said they didn't know the seed cost, and 64 farmers said that their seeds were free, and did not cost them anything because they produced their own seeds.

- Soil. Not all farmers needed to purchase soil because they had enough topsoil on their farm. However, on many of the lava lands, the rocky planting holes must first be filled with topsoil before papaya seeds or seedlings can be put into the ground. For 71 farmers, the average cost of topsoil was $\$ 75$ per acre per year. Six other farmers said they didn't know the cost of soil they purchased, and 16 farmers said they did not have to buy topsoil.

- First year cost difference between growing nontransgenic and transgenic papaya. Comparative first year costs of growing transgenic versus nontransgenic papaya could be obtained only from early adopters, since the survey ended 16 months after the May 1998 seed distribution. Overall, the early adopters felt that there was no difference in the cost of growing nontransgenic or transgenic papayas. The only major change in farming practice was the trend toward using transplanted seedlings for planting the transgenics. This new practice was a learning experience for farmers since the old custom was to sow seeds directly into the planting holes. This survey elicited all of the farmers' opinions on the first year costs of growing nontransgenic versus transgenic papayas (whether they had planted or not): 
- Transgenics cost less: $\quad 2 \%$

- Transgenics cost more: $8 \%$

No difference in cost: $25 \%$

o No comment/not sure: $66 \%$

Since the earliest adopters were in their first four months of harvest, no annual harvest data were collected. However, field trial data over a five year period showed that annual production of Rainbow was greater than $2,242 \mathrm{~kg} / \mathrm{ha} /$ week, or about 116 metric tons/ha/year which is about 3.5 times the industry average for nontransgenic fruit of about 33.1 metric tons/ha/year (1).

\begin{abstract}
Relation of farm sizes to historical acreage, 1999 transgenic and nontransgenic acreage, net change, and percentage of acreage that is transgenic (Table 1). Farms were assigned to four size categories, Small, Medium-small, Medium, and Large, based on a farmer's historical acres (total nontransgenic acres being grown when a farmer first observed Papaya ringspot virus on the farm). Thus, the year corresponding to the reported historical acres occurred between 1992 when Papaya ringspot virus first entered the Puna area, and on through 1997, by which time all respondents had observed Papaya ringspot virus in their fields. Overall, farms were as small as a oneacre plot of land, and as large as 305 acres.
\end{abstract}

Table 1. Relation of farm sizes to historical acreage, 1999 transgenic and nontransgenic acreage, net change, and percentage of acreage that is transgenic in the Puna growing region.

\begin{tabular}{|c|c|c|c|c|c|c|c|c|c|}
\hline \multirow[b]{2}{*}{ Farm size ${ }^{a}$} & \multirow[b]{2}{*}{$\begin{array}{c}\text { Range } \\
\text { acres }\end{array}$} & \multirow[b]{2}{*}{$\begin{array}{c}\text { Avg } \\
(\mathrm{NT}+\mathrm{T}) \\
\text { acres }\end{array}$} & \multirow[b]{2}{*}{$\begin{array}{c}\text { No. } \\
\text { growers }\end{array}$} & \multirow[b]{2}{*}{\begin{tabular}{|} 
Historical $^{\mathrm{b}}$ \\
acreage $^{(\%)}$ \\
$(\%)$
\end{tabular}} & \multicolumn{3}{|c|}{1999 Papaya acreage } & \multirow[b]{2}{*}{$\begin{array}{c}\text { Net change } \\
\text { ( NT-Historical) } \\
\text { as: acres (\% } \\
\text { of Historical) }\end{array}$} & \multirow[b]{2}{*}{$\begin{array}{l}\% \text { T acres } \\
\text { farm size } \\
T /(N+T)\end{array}$} \\
\hline & & & & & $\begin{array}{c}\text { Non- } \\
\text { transgenic } \\
\text { NT }(\%)^{\mathrm{C}}\end{array}$ & \begin{tabular}{|c} 
Transgenic \\
T (\%)
\end{tabular} & $\begin{array}{l}\text { Total } \\
\text { NT+T }\end{array}$ & & \\
\hline Large & $86-305$ & 162 & 4 & $565(40)$ & $354(35)$ & $292(37)$ & 646 & $-211(-37)$ & 45 \\
\hline Medium & $21-49.9$ & 28 & 21 & $344(24)$ & $314(32)$ & $274(34)$ & 588 & $-30(-9)$ & 47 \\
\hline Med.-small & $6-20.9$ & 11 & 45 & $403(28)$ & $312(31)$ & $190.5(24)$ & 502.5 & $-91(-23)$ & 38 \\
\hline Small & $1-5.9$ & 3 & 20 & $78(6)$ & $23(3)$ & $36.5(5)$ & 59.5 & $-55(-71)$ & 61 \\
\hline No farm/1999 & 0 & 0 & 3 & $33(2)$ & $0(0)$ & $0(0)$ & 0 & $0(-100)$ & 0 \\
\hline & & Total & 93 & $1423(100)$ & $1003(100)$ & $793(100)$ & 1796 & $-420(-30)$ & -- \\
\hline
\end{tabular}

a Farm size is defined by the range of acres in each category. For example, acreage of Small farms ranged from 1 to 5.9 acres and for the four Large growers the farm acreage ranged from 86 to 305 acres.

b Historical acres refers to the total papaya acreage in the Puna region just prior to the first observation of papaya ringspot virus infection on papaya. Thus, historical data was reported for different years, from 1992 when papaya ringspot virus first entered the Puna area, to 1997 at which time all farmers in this survey had observed infected plants

in their fields.

c Percent of acreage by farm size.

Source: Gonsalves, Lee, and Gonsalves, 2004

Concerning the average of farmers' total nontransgenic and transgenic (NT +T) acreage, Large farmers had an average of 162 acres; Medium farmers, 28 acres; Medium-small farmers, 11 acres; and Small farmers, 3 acres. Only 4 of the 93 farmers had Large farms, but they grew $646(36 \%)$ of the 1,796 total nontransgenic and transgenic acres. Most of the farmers had either Medium or Mediumsmall farms that ranged from 21 to 49.9 acres, or 6 to 20.9 acres, respectively. Overall, 66 growers ( $71 \%$ of the farmers) had Medium or Medium-small sized farms and they grew a combined total of 
$1,090.5$ acres which accounted for $61 \%$ of the current (1999) total nontransgenic and transgenic acres. The Small farm category contained 20 growers, but they grew only $3 \%$ of the papaya acres.

In 1999, the surveyed farmers grew 1,796 total NT+T acres compared to 1,423 historical acres, a $21 \%$ increase. The increase in acreage was due to the adoption of transgenic papaya, since only 1,003 acres of nontransgenic papaya were grown by these farmers in 1999 , a decrease of $30 \%$ from the historical acre levels. Thus, in 1999 transgenic papaya occupied 793 of the 1,796 acres or $44 \%$. The percent of transgenic papaya acres grown on each type of farm ranged from $38-61 \%$.

Small farmers experienced the greatest decrease in current (1999) nontransgenic acreage compared to their historical acreage (-71 acres), yet they showed the highest adoption rate $(61 \%)$ of transgenic papayas. The basis for this high adoption rate is not known; however, we can speculate that they wanted to grow transgenic papayas to make up for the losses caused by Papaya ringspot virus. This is a plausible explanation, especially since the farmers' major reason for deciding to plant transgenics was that they thought the plants were resistant to Papaya ringspot virus.

\section{Farmer ratings of the Rainbow variety showed a high acceptance of transgenic Rainbow fruit with respect to its sweetness and firmness, and the plants' resistance to Papaya ringspot virus.}

Farmer attitudes toward buying transgenic seeds and trying new transgenic varieties (Table 2 ).

Table 2. Farmer attitudes toward buying transgenic seeds and trying new transgenic varieties

\begin{tabular}{|l|c|c|c|}
\hline \multirow{2}{*}{ Questions } & \multicolumn{2}{|c|}{ Farmer responses (\%) } \\
\cline { 2 - 4 } & Yes & No & Not sure \\
\hline $\begin{array}{l}\text { Currently the transgenic seeds are given free } \\
\text { to the farmer. If in the future, the seeds are } \\
\text { sold, would you be willing to buy them? }\end{array}$ & 86 & 13 & 1 \\
\hline $\begin{array}{l}\text { If new transgenic varieties other than Rainbow } \\
\text { or SunUp are introduced, are you interested in } \\
\text { trying them? }\end{array}$ & 88 & 0 & 12 \\
\hline $\begin{array}{l}\text { Do you think it's important to label Rainbow or } \\
\text { SunUp so that the consumer knows that these } \\
\text { are transgenic fruit? }\end{array}$ & 77 & 12 & 11 \\
\hline
\end{tabular}

Source: Gonsalves, C. 2001

Farmer acceptance of transgenic papaya was demonstrated by their willingness to buy transgenic seed in the future (86\%), even though they were currently receiving the seeds free of charge. The primary qualification by respondents was that the price of the seed should be "reasonable." If a new transgenic papaya cultivar were to be distributed, $88 \%$ of the farmers said they would be interested in trying it. When asked whether it is important to label Rainbow or SunUp so the consumer knows that these are transgenic fruit, a large number $(77 \%)$ of farmers said "Yes," but their reasons for doing so was that they felt that labeling would increase marketability of their fruit $(57 \%)$ and would provide information for consumers (35\%). The tenor of farmer responses (although no data was taken) was that 
they had a superior product and they wanted consumers to know it. Nevertheless, $25 \%$ of the farmers who were in favor of labeling were conscious of consumers' "need to know" whether a fruit was transgenic or not. Farmers who were not in favor of labeling thought that labeling was not necessary and that papaya should be marketed according to the quality of the fruit. Interesting comments from two of the eleven farmers who were not in favor of labeling were that mislabeled fruit could cause a problem in the marketplace. An example would be the problem caused when a fruit is expected to be yellow-fleshed (such as the transgenic Rainbow) but is found to be red-fleshed, like the nontransgenic Sunrise variety. Another farmer saw labeling as a problem for marketing because some people don't like transgenic fruit. Ten of the eleven farmers who were not sure about the idea of labeling had no comment, and one felt that labeling is too much work for the farmer.

\section{Update 2004}

Farmers endured the scourge of Papaya ringspot virus a full six years, from 1992 to 1998, before Rainbow and SunUp were offered as a solution to their problem. The promise of a papaya that could remain healthy via engineered virus resistance was a hope that in truth became a reality for farmers who adopted these high tech varieties $(4,5)$. Moreover, the virus-resistant Rainbow, a hybrid between transgenic red-fleshed SunUp and the traditional yellowfleshed Kapoho solo, is sweeter and has greater production than Kapoho solo and has inherited the yellow flesh of Kapoho solo, a trait much desired by the industry $(1,4,5)$.

Enthusiastic farmer acceptance of Rainbow documented in the 1999 farmer survey reported here shows the phenomenally high and rapid rate of adoption with $76 \%$ of the 93 farmers planting their Rainbow seeds. At the time this survey was completed, 16 months after the papaya seeds first became available to farmers, $19 \%$ of the farmers were already harvesting their first crop of Rainbow. For a perspective on the significance of the 1,796 acres grown by the 93 farmers in this survey (Table 2), which was completed in September 1999 , it is important to note that this represents $79 \%$ of the 2,275 acres in crop for the entire island of Hawaii for about the same period of time (September 1999), as reported by the Hawaii Agricultural Statistics Service (8).

In August 2000, nearly a year following this survey, HASS reported that Rainbow was the dominant papaya cultivar in Hawaii, comprising 50 percent of the state's bearing acreage $(2,8)$. In this same year, in Puna, HASS reported that Rainbow was planted on 40 percent of the island of Hawaii's current 2,050 total papaya acreage, and that Rainbow accounted for 50 percent of the island's bearing acreage (8). Fresh papaya utilization of combined transgenic and nontransgenic production from the Puna area was 26 million pounds ( $75 \%$ percent statewide production) in 1998, the year the transgenic seeds became available to farmers. In 2000, it was, 33 million pounds (68\% percent statewide), and in 2002, it was 35 million pounds ( $84 \%$ statewide) (5). The average farm price for fresh papaya was 25 cents per pound in 1992, when the virus first began infecting trees in Puna. However, due to sharp losses in the availability of papaya caused by the burgeoning viral epidemic, farm prices increased yearly, until it peaked at 52.9 cents per pound in 1997. By this time, Hawaii produced an annual 20 million pounds less fruit than in 1992. In the July 12, 2004 HASS report, preliminary data showed that farmers 
were receiving 37 cents for each pound of fruit sold during the month of June (10). The price fluctuates based on the supply and demand for papayas, and basically is the price that farmers who contract to sell to the packing houses receive. Independent non-contracted farmers might receive a lower farm price; however, due to their farm efficiencies, large quantities of production, higher quality fruit with higher pack out, and generally, a guaranteed market, these independent farmers have a positive advantage. Based on farm value, papaya has maintained an eighth place ranking in the State of Hawaii's "Top 20 commodities," and continues to be Hawaii's second most important fruit crop (9). Much of this data has been reviewed indepth by Gonsalves, et al. (5).

Are farmers still enthusiastic about growing this variety six years after Rainbow was introduced? The answer is clearly "Yes!" Although a parallel survey to the one reported here has not been done, we introduce "snapshots" captured in photos and words to illustrate some of the events going on in Hawaii today. Although it is impossible to represent all the complexities inherent within the papaya industry, these "snapshots" will provide a good starting point for understanding the growers' current perspectives.

William and Catherine J ulian grow only Rainbow papaya on their 200 acre farm, producing three to four million pounds a year. Willie carefully manages both fallow and producing lands and does his own handling and packing with the aid of 13 employees. Cathy has a full time off-farm job, but also helps with the farm work as time permits. Weekly, all papaya destined for off-island sales are shipped to produce wholesalers on Oahu via Young Brothers barge service. Eighty percent of their papayas is sold in Hawaii and $20 \%$ in Canada. The Julians receive 25 cents per pound of fruit sold. Weekly shipments from W \& C Julian Farms run from highs of 100,000 pounds to lows of 50,000 pounds, depending on the papaya fruiting cycle and factors that affect production such as drought and rain. The trees sometimes develop disease problems such as blackspot, but these don't kill the plants and are treatable with proper sprays. Willy said, "I tell you the truth, if not for Rainbow, I wouldn't be growing papaya."

Reflecting back, Willie noted that if he decided to grow Kapoho solo again, it would be better if he weren't a papaya farmer. His disinterest in growing this virus-susceptible variety stems from devastating losses suffered when he had been growing 150 acres of Kapoho solo before Rainbow became available. When Papaya ringspot virus hit their fields it caused them to "lose plenty money." At the time, they had eight to nine employees, whom they didn't want to let go. Among other tasks, the workers were kept busy with constant monitoring and eradicating of every virus-infected tree they found in the fields. The results were disappointing. Due to heavy virus pressure in their area, Willie had to depend more on his sideline businesses to supplement his papaya farm income, that of hauling water to homeowners in Puna who need to purchase water when their rainfed water tanks run low, and doing more land clearing work for other farmers. 

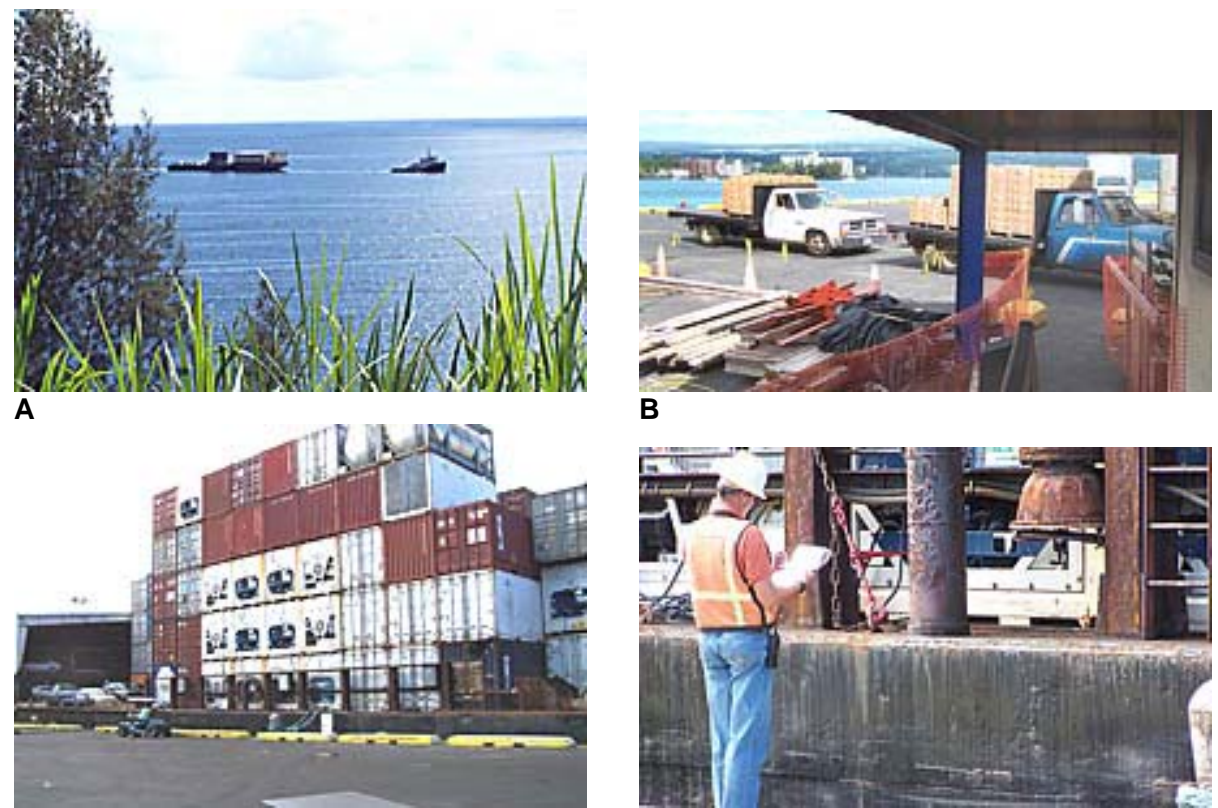

B

Fig. 9. July 2004: Young Brothers barge service provides a crucial commercial connection between the Hawaiian islands (A). Farmers drive to the dock to have their shipments weighed and loaded into containers. About 24 farmers ship a combined weight of 100,000 pounds of papaya from Hilo to Oahu weekly (B). Close up of containers loaded with papayas (C). Temperature-controlled containers are carefully monitored to guarantee peak freshness (D).
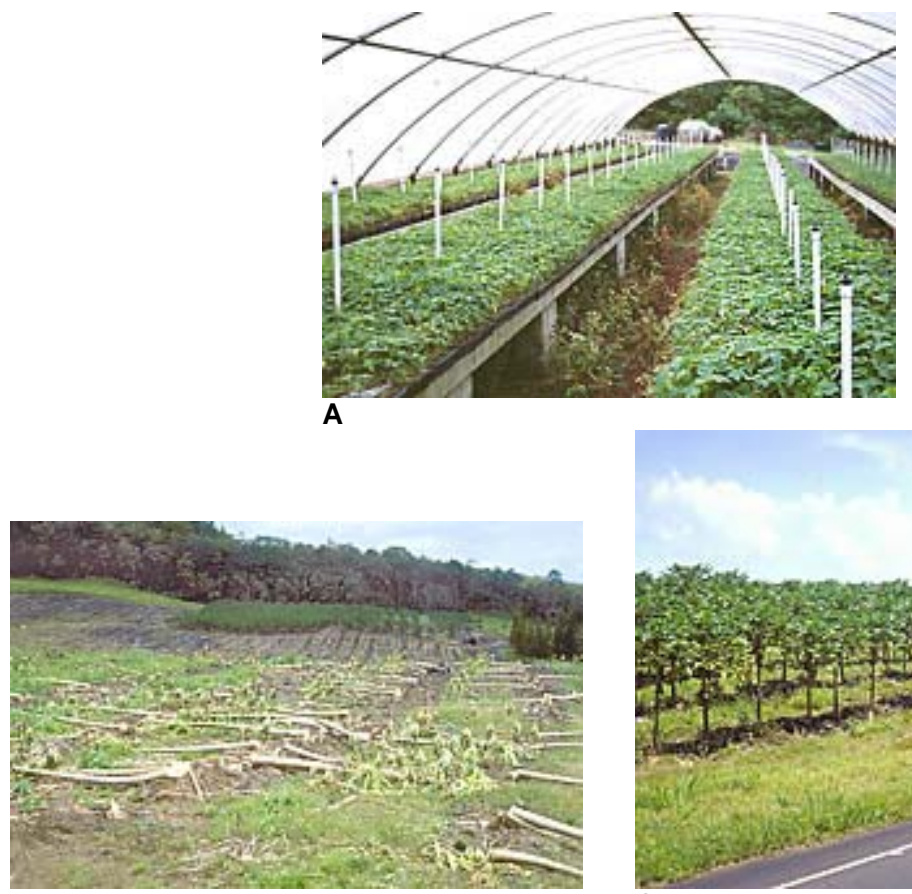

B

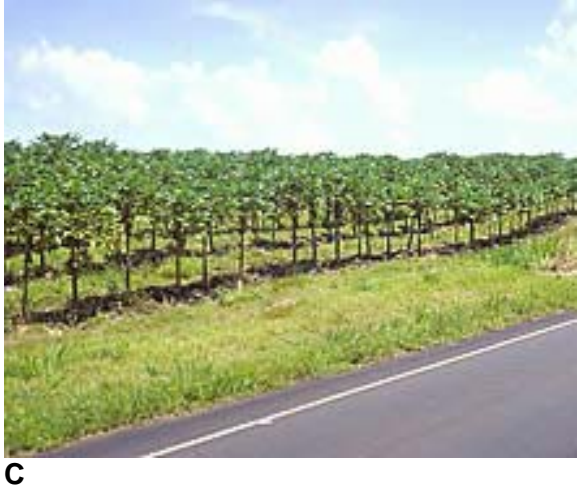

Fig. 10. At W\&C Julian Farms: Preparation of Rainbow seedlings (A), removal of virussusceptible Kapoho solo (B), and replanting with Rainbow (C).

Hawaii Papaya I ndustry Association (HPI A). Since 1971 the Papaya Administrative Committee was the organization to which all papaya growers belonged, and it was in existence at the time this survey was planned and executed. However, based on the results of a grower referendum, the marketing order was terminated, and HPIA succeeded the PAC on October 1,2002. This statewide association of papaya growers had been in existence since 1965. Membership is voluntary, and so are submission of production records, and 
contributions made to the HPIA to continue to conduct research on papaya production and marketing research, and on development and advertising, compared to mandatory contributions previously required by the PAC $(4,5)$.

A spokesperson for HPIA has said that since it is not an entity of the USDA, under which PAC existed as a Federal Marketing Order, they can no longer distribute the seeds for free. Thus, under a contract with the PAC, which still holds, Rainbow seeds are produced by Hawaii Agricultural Research Center (HARC) and HPIA distributes the seeds to growers for a fee. The price per ounce of seed differs for growers $(\$ 20.00, \$ 60.00$, or $\$ 135.00$ per ounce) based on whether the grower is in "good standing" with the HPIA. The qualification of "good standing" is determined by whether the grower is current with dues ( $\$ 15.00$ annually) and contributes to the industry's voluntary production contribution program at the rate of $\$ 0.004$ per pound of fresh papaya sold per year.

Rainbow and SunUp seeds are also available to backyard growers in packets of 50 seeds, for a minimal fee. The seeds are available from the University of Hawaii (Manoa Campus) Seed laboratory. Backyard growers must follow the same procedures as the commercial papaya growers by viewing an educational video, signing a registration form, and signing the licensing agreement. The seeds may only be planted in the state of Hawaii.

Papaya packing companies in the Puna area. A number of papaya farmers pack and ship their own papayas by barge or air freight them to Hawaii markets and to Canada. However, since produce from the state of Hawaii is under a Federal fruit fly quarantine, all papayas destined for the U.S. mainland must be treated to prevent the transfer of fruit fly larvae or eggs to mainland farming areas where there is a possibility that the flies could breed and damage mainland crops. Three packing houses in Keaau, in the Puna area, are equipped to provide services that meet the requirements of the Animal Plant Health Inspection Service (APHIS). Hawaii Pride uses an electronic irradiation system, while Diamond Head Papaya and Tropical Hawaiian Products use a vapor heat treatment.

Diamond Head Papaya Company produces six million pounds of papaya per year. Japan purchases $60 \%$ of the papayas, U.S. mainland, $35 \%$, and $5 \%$ are sold locally. Since Japan is still in the process of deciding whether they will approve imports of the transgenic Rainbow, Diamond Head Papaya Company pays meticulous attention to assure that their contracted farmers do not plant Rainbow, and that Rainbow is not processed in the packing plant. As non-adopters of the virus-resistant Rainbow variety, Diamond Head Papaya Company must constantly monitor for Papaya ringspot virus in their fields. Infected trees must be cut down so that feeding aphids will not spread the virus to healthy trees. The cost of complying with the Plant Variety Protection (PVP) protocol (5), along with the losses caused by Papaya ringspot virus, take a heavy toll on profits. A company spokesperson said that they used to produce twice as much papaya, and that the drop in production is directly attributable to Papaya ringspot virus. The company also faces heavy competition in Japan from papaya grown in the Philippines which can be sold more cheaply in Japan due to their lower cost of production and transportation. 
Tropical Hawaiian Products' varietal production is 50\% Rainbow and $50 \%$ Kapoho solo. Eighty percent of their fruit goes to U.S. mainland markets, $20 \%$ to Japan, and some are sold in Hawaii. When handling and packing for Japan, only the nontransgenic papaya variety is allowed in the packing plant. Tropical Hawaiian Products also helps to monitor their contract farmer fields for Papaya ringspot virus. Farmers suffer losses from Papaya ringspot virus on the nonresistant Kapoho solo, but are offered a 10 to 20 cent per pound premium for this variety.

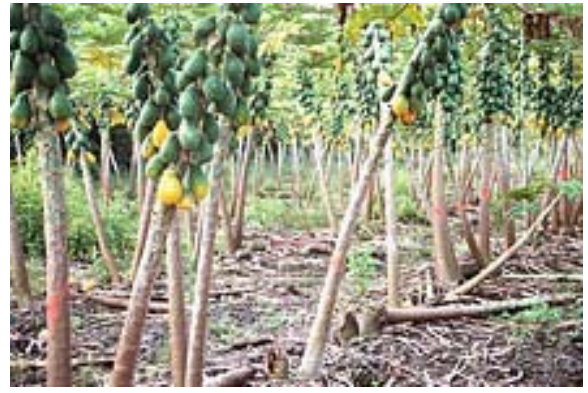

A

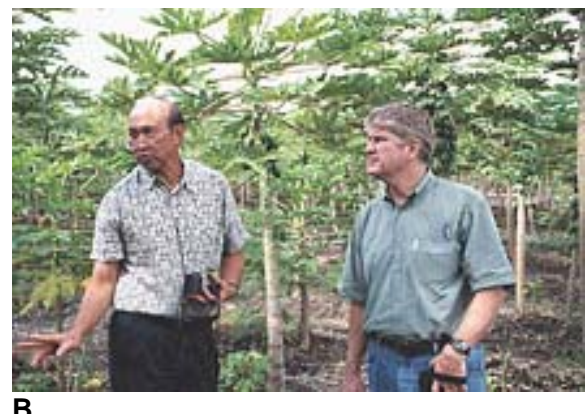

Fig. 11. Papaya ringspot virus is as devastating today as it has always been for nontransgenic, PRSV susceptible varieties. Workers from the packing houses such as Tropical Hawaiian Products and Diamond Head Papaya help to educate contracted farmers about the need to cut down infected trees to help prevent further spread of the virus, but when trees are laden with fruit many farmers do not want to cut their trees. The orange paint marks the infected trees (A). Dennis Gonsalves and David Lee observe profound viral damage in a farmer's field $(B)$.

Rudy Sibucao was one of the first farmers to discover Papaya ringspot virus on his Puna farm in 1992. A year ago he decided to stop growing papayas in Puna, but to continue with his farm at Wainaku, just outside of Hilo, where he grows Kapoho solo (50\%), Rainbow, and a Kapoho solo hybrid ( $25 \%$ each). He does all of the farming himself with the help of part timers who work two days a week on his medium sized farm. Papaya ringspot virus pressure is much milder in this area since he doesn't have other papaya farmers nearby and he strictly monitors and removes virus-infected nontransgenic trees as a control method. His premium fruit, about 3,500 to 4,000 pounds per week, are carefully selected so the fruit can be marketed at a slightly riper stage than usual. Papayas are sent via Aloha Airlines to his buyer on Oahu who distributes the fruit to markets in Europe, Canada, and Hawaii. Rudy receives 40 cents per pound for his papaya regardless of the variety. Another 1,000 pounds per week of Kapoho solo is sold to Hawaii Fresh, a company which services the Japan market. Rudy receives 25 cents per pound of fruit from this buyer. 


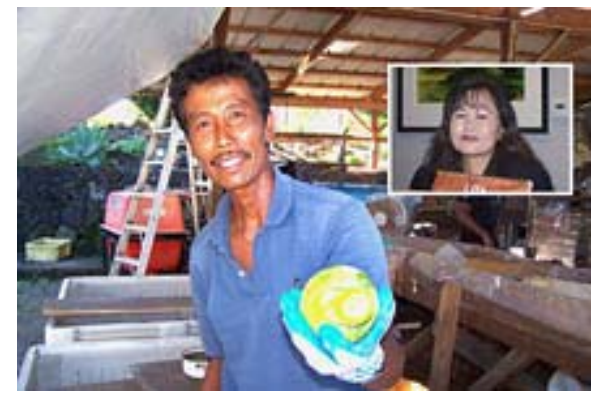

Fig. 12. Seen here with a freshly picked papaya, Rudy Sibucao trucks his papayas home for preparation and packing. Typical of many farm families, working with the papayas is a family affair that is enjoyed even by family members who have off-farm jobs. Rudy's wife, Lita (inset) works full time at a local bank, but spends two half-days helping to pack the fruit along with their son who is a mechanic but also makes time to come to the farm with friends to help pack the fruit.

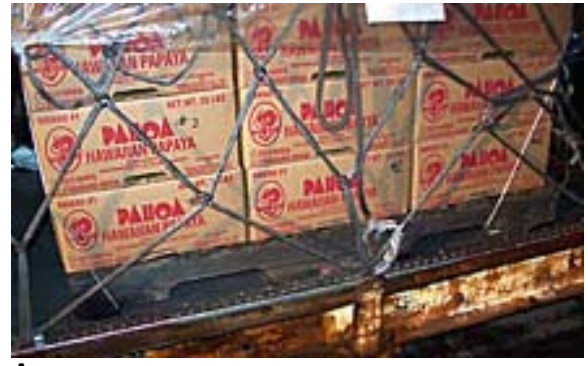

A

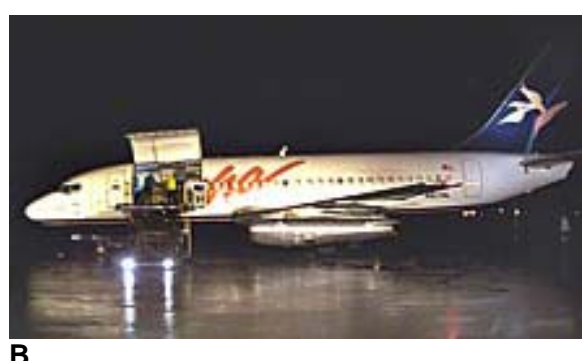

B

Fig. 13. July 2004: Rudy Sibucao and other independent farmers, as well as Tropical Hawaiian Products and Diamond Head Papaya ship their papayas between islands by Aloha Airlines. Seen here at about 10 p.m. is an Aloha Airlines cargo plane with pallets of papaya to be loaded and sent off to Oahu where they are sold or transferred by other carriers to distant ports.

\section{Parting Words}

Rainbow is a papaya variety that was genetically engineered to resist infection from a virus which weakens and eventually kills papaya trees. Papaya ringspot virus entered Puna, Hawaii's major papaya growing area, in 1992, and by 1994 all farming areas in Puna, where up to $96 \%$ of Hawaii's papaya crop was grown, had become infected. Papaya ringspot virus has been credited as the major factor for production losses in the Puna area, which dropped from 53 million pounds of fresh fruit in 1992 to 27.8 million pounds in 1997 (5). Due to a foresight of this problem occurring, scientists had already developed the Rainbow hybrid and its transgenic parental line, SunUp, and these were being tested in a field trial in Puna. Rainbow and SunUp became commercially available to farmers in May 1992, and provided an opportunity whereby farmers now had a choice to grow either the susceptible varieties or the resistant ones. Data from our farmer adoption study on Rainbow show a phenomenally high and rapid rate of adoption of this transgenic Rainbow variety. Farmers also were satisfied with the horticultural characteristics of Rainbow. Additionally, statistical reports show that Rainbow is a major variety grown in Hawaii today (8). Overall, Rainbow has been enthusiastically adopted by farmers and stably integrated into consumer markets in Hawaii, Canada, and the U.S. mainland. 


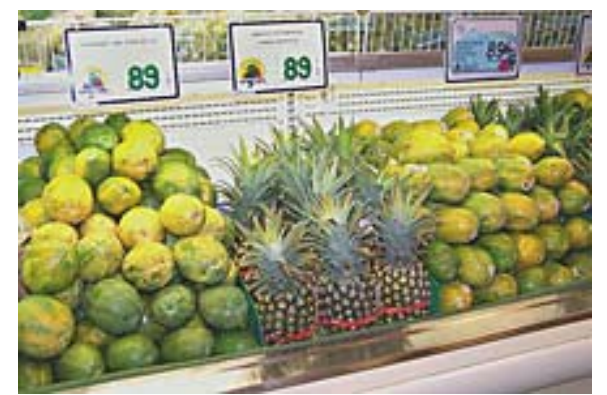

Fig. 14. In larger supermarkets such as this one in Hilo, consumers have their daily pick of Rainbow and other varieties. Pricing is determined by quality of the papayas and not on whether they are genetically engineered or not.

\section{Literature Cited}

1. Ferreira, S. A., Pitz, K. Y., Manshardt, R., Zee, F., Fitch, M., and Gonsalves, D. 2002. Virus coat protein transgenic papaya provides practical control of Papaya ringspot virus in Hawaii. Plant Dis. 86: 101105.

2. Gonsalves, C. 2001. Transgenic virus-resistant papaya: Farmer adoption and impact in the Puna area of Hawaii. Master of Arts, Liberal Studies SUNY Empire State College (Thesis). New York.

3. Gonsalves, C., Lee, D. R., and Gonsalves, D. 2004. Development, Adoption and Commercialization of the Transgenic Virus-Resistant Papaya in Hawaii. Unpublished manuscript. Pacific Basin Agricultural Research Center, Hilo, Hawaii, and Department of Applied Economics and Management, Cornell University, I thaca, N.Y.

4. Gonsalves, D., Ferreira, S., Manshardt, R., Fitch, M., and Slightom, J. 1998. Transgenic virus resistant papaya: New hope for control of Papaya ringspot virus in Hawaii. Online. APSnet Feature, American Phytopathological Society.

5. Gonsalves, D., Gonsalves, C., Ferreira, S., Pitz, K., Fitch, M., Manshardt, R., and Slightom, J. 2004. Transgenic virus resistant papaya: From Hope to Reality for Controlling of Papaya ringspot virus in Hawaii. Online. APSnet feature, American Phytopathological Society.

6. The Papaya J ournal. March 31, 1998. Vol. II, No. 2. "Papaya Administrative Committee (PAC) Transgenic Seed Distribution Plan, 7 pp.

7. USDA/AMS. 1966. Freedom of Information Act. Washington, D.C.; United States Department of Agriculture/ Agricultural Marketing Service.

8. USDA/HAS. 2000. Hawaii Papayas (J anuary 12, 2000). Online. Hawaii Agric. Statistics, Nat. Agric. Statistics Serv. (NASS), Honolulu.

9. USDA/HASS. 2002. Hawaii Agricultural Statistics. Top 20 Commodities, State of Hawaii, 2001-2002. Online. Hawaii Agric. Statistics, Nat. Agric. Statistics Serv. (NASS), Honolulu.

10. USDA/HASS. 2004. Hawaii Papayas (J uly 12, 2004). Online. Hawaii Agric. Statistics, Nat. Agric. Statistics Serv. (NASS), Honolulu.

(c) Copyright 2004 by The American Phytopathological Society American Phytopathological Society 3340 Pilot Knob Road St. Paul, MN 55121-2097

e-mail: aps@scisoc.org 